\title{
Levels of some heavy metals in six species of fish obtained from Challawa River, Kano
}

\author{
Habib Y. TAOHEED* and Dayyab M. SAID \\ Department of Pure and Industrial Chemistry, Bayero University, Kano, \\ P.M.B 3011, Kano, Nigeria. \\ *Corresponding author; E-Mail: ayinde_hato@yahoo.com, \\ Tel: +23408062069691, 08058711697
}

\begin{abstract}
Concentrations of $\mathrm{Co}, \mathrm{Cr}, \mathrm{Mn}, \mathrm{Ni}$ and $\mathrm{Pb}$ were determined in muscle, bone, skin and head of six species of fish obtained from Challawa River along Yan danko village in Kano State. The heavy metals content were determined using Atomic Absorption Spectroscopy (AAS) and expressed in $\mu g^{-1}$ after acid digestion of the samples. The mean concentrations range obtained for the metals analysed in the fish species are as follows; Co

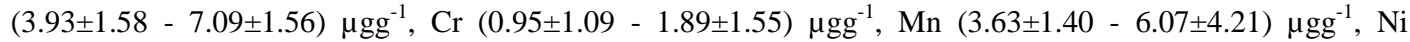
$(1.83 \pm 1.40-3.30 \pm 1.40) \mu \mathrm{gg}^{-1}, \mathrm{~Pb}(0.53 \pm 0.61-1.06 \pm 0.86) \mu \mathrm{gg}^{-1}$. The trend of heavy metal concentration in the fish samples can be represented as: $\mathrm{Co}>\mathrm{Mn}>\mathrm{Ni}>\mathrm{Cr}>\mathrm{Pb}$. The concentrations of $\mathrm{Ni}, \mathrm{Cr}$ and $\mathrm{Pb}$ were below the permissible limits specified by most food regulatory bodies (FAO, WHO, FEPA and USFDA), while Co and Mn levels in the fish species was higher than the maximum permissible limits. Thus, fish species from Challawa River, harvested at Yan danko village are not fit for human consumption.

(C) 2014 International Formulae Group. All rights reserved.
\end{abstract}

Keywords: AAS, acid digestion, Challawa River, fish species, heavy metals.

\section{INTRODUCTION}

The pollution of the aquatic environment with heavy metals has become a great concern worldwide in recent years, because they are indestructible and most of them have toxic effect on organisms (McFarlane and Burchett, 2000). Heavy metals may enter aquatic systems from different natural and anthropogenic (human activities) (Yilmaz, 2009).

Most heavy metals have no beneficial functions to the body and can be highly toxic. Depending upon their concentration, they may exert beneficial or harmful effects on plants, animals and human life (Forstner and Wittman, 1981). At low levels, heavy metals such as copper, cobalt, zinc, iron and manganese are essential for enzymatic activity and many biological processes, but metals such as cadmium, mercury and lead have no known essential role in living organisms, and are toxic at even low concentrations. The essential metals also become toxic at high concentration (Bryan, 1976). However, if they enter into the body through inhalation, ingestion and skin absorption they accumulate in the body tissue faster than the body's detoxification pathways can dispose of them 
(Ekpo et al., 2008). High concentration exposure is not necessary to produce a state of toxicity in the body tissue and, overtime, can reach toxic concentration levels (Prusty, 1994). Heavy metals acquired through the food chain as a result of pollution are potential chemical hazards, threatening consumers.

Aquatic foods have essential amino acids, fatty acids, protein, carbohydrates, vitamins and minerals. Among sea foods, fish is commonly consumed and, is a connecting link for the transfer of toxic heavy metals in human beings (Shrivastava et al., 2011). Fish samples can be considered as one of the most significant indicators in aquatic environment for the estimation of metal pollution (Rasheed, 2001). Fish and shell fish accumulate metals to concentration many times higher than present in water or sediment (Gumgum et al., 1994; Olaifa et al., 2004). Investigation of the distribution and concentration of heavy metals in water, sediment and biota is fundamental to the study of aquatic pollution (Al-Khafaji, 2001).

This study was aimed at assessing the levels of $\mathrm{Co}, \mathrm{Cr}, \mathrm{Mn}, \mathrm{Ni}$ and $\mathrm{Pb}$ in six species of fish (Alestes nurse, Lates niloticus, Heterotis niloticus, Synodontis betensoda, Tilapia zillii and Clarias gariepinus) collected from Challawa River along Yan danko village in Kumbotso L. G. A., Kano State, Nigeria.

\section{MATERIALS AND METHODS \\ Reagents}

All reagents used were AnalaR grade. Deionised water was used throughout to avoid interferences by other ions. All plastic and glassware used were washed with detergent, rinsed with water and soaked in $10 \%(\mathrm{v} / \mathrm{v})$ $\mathrm{HNO}_{3}$ overnight. They were rinsed with deionised water and dried prior to use.

\section{Sampling area and sampling}

Sampling area is Challawa River (N $11^{\circ} 52.745^{\prime}$, E $008^{\circ} 28.473^{\prime}$ ) located along Yan danko village in Kumbotso Local Government Area of Kano State, Nigeria. This site is where raw industrial effluent, primarily from food, textile and tannery industries is discharged into the river.

Six species of fresh fish samples (3-6 individual of each species) namely, Alestes nurse, Lates niloticus, Heterotis niloticus, Synodontis betensoda, Tilapia zillii and Clarias gariepinus were collected directly from the River. These fish species were put in sterile polythene bags and taken in icebox and transported to the laboratory for identification by an expert in the Department of Biological Sciences, Bayero University, Kano, for analysis.

\section{Sample Preparation and Digestion Procedure}

The fish samples were rinsed with deionised water, scales were removed (where necessary). The head, bone, muscle and skin of each fish samples were oven dried at 105 ${ }^{\circ} \mathrm{C}$ until they reached a constant weight. Each dried tissue of the species was homogenized and ground into powder, using porcelain mortar and pestle. They were put in dry labelled plastic containers and stored in desiccators until digestion. $1.0 \mathrm{~g}$ of the fish sample was weighed in each case, transferred into a $100 \mathrm{~cm}^{3}$ beaker, $15 \mathrm{~cm}^{3} \mathrm{HNO}_{3}$ and 5 $\mathrm{cm}^{3} \mathrm{HClO}_{4}$ were added respectively, the beaker with its content was covered with watch glass, and the solution was heated to dryness. The residue was allowed to cool, 5 $\mathrm{cm}^{3}$ of $6 \mathrm{M} \mathrm{HNO}_{3}$ was then added and the content boiled for 2 minutes; $15 \mathrm{~cm}^{3}$ deionised water was then added to the mixture after cooling; it was transferred into $100 \mathrm{~cm}^{3}$ volumetric flask and made up to the mark with deionised water (Sa'id, 2006).

Blank experiment was carried out involving all the reagents and procedure used for the actual digestion but without the sample (Sa'id, 2006). The digests were kept in labelled plastic bottles and later the heavy metal concentrations were determined using a Buck Scientific, 210VGP Atomic Absorption Spectrophotometer (AAS). 


\section{RESULTS AND DISCUSSION}

The concentration of heavy metals in the various parts of the fish samples as well as mean concentrations, ranges and standard deviations are given in Tables $1-5$.

From Table 1, the concentration of cobalt varied from ND (Not detected) in the muscles of Synodontis betensoda, and Clarias gariepinus to $9.43 \mu \mathrm{g} / \mathrm{g}$ in the head of Tilapia zillii and skin of Heterotis niloticus. Base on the mean concentration of cobalt in the fish species, the maximum concentration of cobalt of $7.08 \pm 1.57 \mu \mathrm{g} / \mathrm{g}$ and $7.09 \pm 1.56 \mu \mathrm{g} / \mathrm{g}$ were detected in Tilapia zillii and Lates niloticus respectively and the least cobalt concentration were detected in Alestes nurse, Synodontis betensoda, and Clarias gariepinus; $3.93 \pm 1.58$ $\mu \mathrm{g} / \mathrm{g}, \quad 3.93 \pm 3.02 \mu \mathrm{g} / \mathrm{g}$ and 3.94 $\pm 3.02 \mu \mathrm{g} / \mathrm{g}$ respectively. Cobalt is an essential nutrient for humans, and also forms an integral part of vitamin $B_{12}$ (Sivapermal et al., 2007). Co has also been found to enhance proper thyroid function. Deficiency resulting from Co intake causes anaemia. Excessive intake of $\mathrm{Co}$ is however, reported to cause congestive heart failure and polycythemia (Alexander, 1972).

Chromium is an essential trace metal and the biologically usable form of $\mathrm{Cr}$ plays an essential role in glucose metabolism. Chromium concentration in the various part of the fish sampled ranged from ND to 3.79 $\mu \mathrm{g} / \mathrm{g}$. The mean concentration of chromium revealed that the highest level of $1.89 \pm 1.55$ $\mu \mathrm{g} / \mathrm{g}, 1.89 \pm 1.54 \mu \mathrm{g} / \mathrm{g}, 1.89 \pm 1.55 \mu \mathrm{g} / \mathrm{g}$ were obtained in each of Heterotis niloticus, Synodontis betensoda, and Tilapia zillii respectively, while the lowest level of $0.95 \pm 1.09 \mu \mathrm{g} / \mathrm{g}$ was obtained in Clarias gariepinus. The maximum guideline, $12-13$ $\mu \mathrm{g} / \mathrm{g}$ stipulated by the USFDA (1993a) was however higher than the concentrations of $\mathrm{Cr}$ measured in all the fish samples. Chromium does not normally accumulate in fish and hence low concentrations of $\mathrm{Cr}$ were reported even from the industrialized parts of the world (Moore and Ramamoorthy, 1984).
Manganese was detected in the entire samples studied. The concentration in the various parts was between ND in the muscles of Lates niloticus, Synodontis betensoda and Clarias gariepinus to $9.72 \mu \mathrm{g} / \mathrm{g}$ in the skin of Clarias gariepinus. Levels of $\mathrm{Mn}$ accumulation in the fish species revealed that Alestes nurse have the lowest concentration of $3.63 \pm 1.40 \mu \mathrm{g} / \mathrm{g}$, while Clarias gariepinus have the highest concentration of $6.07 \pm 4.21$ $\mu \mathrm{g} / \mathrm{g}$. The concentration of $\mathrm{Mn}$ in all the fish samples exceeded the WHO (1989) guideline of $0.01 \mathrm{ppm}$ and FEPA (2003) limits of 0.05 ppm. Mn is an essential element for both animals and plants. Deficiencies of Mn result in severe skeletal and reproductive abnormalities in mammals. It is widely distributed throughout the body with little variation and does not accumulate with age (Sivapermal et al., 2007).

$\mathrm{Ni}$ concentration in the various parts of the fish species varied from ND in the muscle of Alestes nurse, Lates niloticus and Clarias gariepinus to $4.42 \mu \mathrm{g} / \mathrm{g}$ in the skin of Clarias gariepinus. The lowest concentration of $\mathrm{Ni}$ was measured in Alestes nurse, 1.83 \pm 1.40 $\mu \mathrm{g} / \mathrm{g}$ while the highest concentration, $3.30 \pm 1.40 \mu \mathrm{g} / \mathrm{g}$ of $\mathrm{Ni}$ was measured in Heterotis niloticus. The levels of $\mathrm{Ni}$ were found to be higher than the stipulated limits when compared with the estimated maximum guideline of $0.5-0.6 \mathrm{ppm}$ (WHO, 1985; FEPA, 2003) in fish food. On the contrary, the concentrations of $\mathrm{Ni}$ were far below the recommended limits of $70-80 \mu \mathrm{g} / \mathrm{g}$ (USFDA, 1993B). The major source of $\mathrm{Ni}$ for humans is food and uptake from natural sources, as well as food processing (NASNRC, 1975). Increased incidence of cancer of the lung and nasal cavity caused by high intake of $\mathrm{Ni}$ has been reported in workers in Ni smelters.

Lead is classified as one of the most toxic heavy metals. The biological effect of sub-lethal concentration of lead include delayed embryonic development, suppressed 
reproduction and inhalation of growth, increased mucous formation, neurological problem, enzyme inhalation and kidney dysfunction (Rompala et al., 1984). The ranged of lead concentration in various parts of the fish species were between ND to 2.12 $\mu \mathrm{gg}^{-1}$. Mean concentrations of the metal in the individual species showed that Synodontis betensoda had the highest concentration of $1.06 \pm 0.86 \mu \mathrm{gg}^{-1}$ and Tilapia zillii and Lates niloticus both has the lowest concentration of $0.53 \pm 0.61 \mathrm{\mu gg}^{-1}$, Table 5. The concentrations of lead recorded in the fish species under this investigation were lower than the maximum recommended limits of $2.0{\mu g g g^{-1}}$ (WHO, 1985; FEPA, 2003; FAO, 1983) in fish food.

Table 1: Concentrations of cobalt $(\mu \mathrm{g} / \mathrm{g})$ in various parts of the fish samples.

\begin{tabular}{lccccc}
\hline Fish species & Muscle & Bone & Head & Skin & Mean \pm SD \\
\hline Alestes nurse & 3.14 & 6.29 & 3.14 & 3.14 & $3.93 \pm 1.58$ \\
Lates niloticus & 6.29 & 9.43 & 6.29 & 6.33 & $7.09 \pm 1.56$ \\
Heterotis niloticus & 3.14 & 6.29 & 6.29 & 9.43 & $6.29 \pm 2.57$ \\
Synodontis betensoda & ND & 6.32 & 6.29 & 3.12 & $3.93 \pm 3.02$ \\
Tilapia zillii & 6.29 & 6.29 & 9.43 & 6.29 & $7.08 \pm 1.57$ \\
Clarias gariepinus & ND & 3.15 & 6.29 & 6.33 & $3.94 \pm 3.02$ \\
\hline
\end{tabular}

Table 2: Concentrations of chromium $(\mu \mathrm{g} / \mathrm{g})$ in various parts of the fish samples.

\begin{tabular}{lccccc}
\hline Fish species & Muscle & Bone & Head & Skin & Mean \pm SD \\
\hline Alestes nurse & 1.89 & ND & 1.89 & 1.89 & $1.42 \pm 0.95$ \\
Lates niloticus & 1.89 & ND & 1.89 & 1.89 & $1.42 \pm 0.95$ \\
Heterotis niloticus & ND & 1.89 & 3.79 & 1.89 & $1.89 \pm 1.55$ \\
Synodontis betensoda & 1.89 & ND & 1.89 & 3.76 & $1.89 \pm 1.54$ \\
Tilapia zillii & ND & 3.79 & 1.89 & 1.89 & $1.89 \pm 1.55$ \\
Clarias gariepinus & ND & ND & 1.89 & 1.90 & $0.95 \pm 1.09$ \\
\hline
\end{tabular}
ND: Not detected

Table 3: Concentrations of manganese $(\mu \mathrm{g} / \mathrm{g})$ in various parts of the fish samples.

\begin{tabular}{lccccc}
\hline Fish species & Muscle & Bone & Head & Skin & Mean \pm SD \\
\hline Alestes nurse & 2.42 & 4.84 & 4.84 & 2.42 & $3.63 \pm 1.40$ \\
Lates niloticus & ND & 4.84 & 4.84 & 7.31 & $4.25 \pm 3.06$ \\
Heterotis niloticus & 2.42 & 4.84 & 7.26 & 2.42 & $4.24 \pm 2.31$ \\
Synodontis betensoda & ND & 7.30 & 4.84 & 4.81 & $4.24 \pm 3.06$ \\
Tilapia zillii & 2.42 & 7.26 & 4.84 & 4.84 & $4.84 \pm 1.98$ \\
Clarias gariepinus & ND & 7.28 & 7.26 & 9.74 & $6.07 \pm 4.21$ \\
\hline
\end{tabular}

ND: Not detected 
Table 4: Concentrations of nickel $(\mu \mathrm{g} / \mathrm{g})$ in various parts of the samples.

\begin{tabular}{lccccc}
\hline Fish species & Muscle & Bone & Head & Skin & Mean \pm SD \\
\hline Alestes nurse & ND & 2.93 & 2.93 & 1.47 & $1.83 \pm 1.40$ \\
Lates niloticus & ND & 4.40 & 2.93 & 1.48 & $2.20 \pm 1.89$ \\
Heterotis niloticus & 1.47 & 4.40 & 4.40 & 2.93 & $3.30 \pm 1.40$ \\
Synodontis betensoda & 1.47 & 2.95 & 2.93 & 2.91 & $2.57 \pm 0.73$ \\
Tilapia zillii & 1.47 & 2.93 & 2.93 & 1.47 & $2.20 \pm 0.84$ \\
Clarias gariepinus & ND & 2.94 & 2.93 & 4.42 & $2.57 \pm 1.85$ \\
\hline
\end{tabular}

Table 5: Concentrations of lead $(\mu \mathrm{g} / \mathrm{g})$ in various parts of the samples.

\begin{tabular}{lccccc}
\hline Fish species & Muscle & Bone & Head & Skin & Mean \pm SD \\
\hline Alestes nurse & ND & 1.06 & ND & 2.12 & $0.80 \pm 1.02$ \\
Lates niloticus & ND & 1.06 & ND & 1.07 & $0.53 \pm 0.61$ \\
Heterotis niloticus & ND & 1.06 & 1.06 & 1.06 & $0.80 \pm 0.53$ \\
Synodontis betensoda & ND & 1.07 & 1.06 & 2.11 & $1.06 \pm 0.86$ \\
Tilapia zillii & ND & 1.06 & 1.06 & ND & $0.53 \pm 0.61$ \\
Clarias gariepinus & 1.06 & 1.06 & 1.06 & ND & $0.80 \pm 0.53$ \\
\hline
\end{tabular}
ND: Not Detected

\section{Conclusion}

The higher levels of $\mathrm{Co}, \mathrm{Mn}$ and $\mathrm{Ni}$ in the fish species may result in toxic health effects for humans consuming fishes from the river. Hence, the results can be used to evaluate the possible health risk associated with the consumption of the fish species that were analysed. The present study highlighted the need precaution measures to be taken in order to reduce the presence of heavy metals and also the need to enforce the existing environmental laws. The activities of industries located within the vicinity should be kept under strict surveillance as they are capable of increasing the heavy metals discharge into the river. The study shows a need for continuous pollution assessment study of aquatic organisms in the river.

\section{REFERENCES}

Alexander CS. 1972. Cobalt-beer Cardioyopathy, A clinical and pathological study of twenty eight cases. Am. J. Med., 53: 395 - 417.

Al-Khafaji, B. Y. 2001. The Initial assessment of some trace metals in Qarmatt Ali River connected with Shatt Al-Arab. Iraq. J. Biol., 1(1): 175-186.

Bryan GW. 1976. Some effects of heavy metal tolerance in aquatic organisms. In Effects of Pollutants on Aquatic Organisms, Lockwood APM (ed). Cambridge University Press: Cambridge, England; 7.

Ekpo KE, Asia IO, Amayo KO, Jegede DA. 2008. Determination of lead, cadmium and mercury in surrounding water and organs of some species of fish from Ikpoba River in Benin City, Nigeria. Int. J. Phy. Sc., 3(11): $289-292$.

FAO (Food and Agriculture Organization). 1983. Compilation of Legal Limits for Hazardous Substances in Fish and Fishery Products, FAO Fisheries Circular no. 464, 1983, pp. $5-100$.

FEPA (Federal Environmental Protection Agency). 2003. Guideline and Standards for Environmental Pollution and Control in Nigeria. FEPA.

Forstner, U. And Wittman, W. 1981. Metal Pollution in the Aquatic Environment. Springer - Verlag: Berlin, Heidelberg, Germany; 272: 486. 
Gumgum B, Unlu E, Tez Z, Gulsun Z. 1994. Heavy metal pollution in water, sediment and fish from the Tigris River in Turkey. Chemosphere, 29: 111 - 116.

Mcfarlane GB, Burchett MD. 2000. Cellular distribution of $\mathrm{Cu}, \mathrm{Pb}$ and $\mathrm{Zn}$ in the Grey Mangrove Avicemnia marina (Forsk). Vierh Aquat. Bot., 68: 45 - 49.

Moore JW, Ramamoorthy S. 1984. Heavy Metals in Natural Waters Applied Monitoring and Impact Assessment. Springer-Verlag: New York; 268.

NAS - NRC (National Academy of SciencesNational Research Council). 1975. Division of Medical Sciences, Medical and Environmental Effects of Pollutants Nickel. National Academy Press: Washington D.C.

Olaifa FE, Olaifa AK, Adelaja AA, Owolabi AG. 2004. Heavy metal contamination of Clarias garpinus from a lake and fish farm in Ibadan, Nigeria. Afric. J. Biomed. Res., 7: 145 - 148.

Prusty AW. 1994. The use of fish in monitoring water pollution. Tour Biotech. Pp. $4-7$.

Rasheed MN. 2001. Monitoring of environmental heavy metals in fish from Nasser Lake. Environ. Int., 27: 27 - 33.

Rompala JM, Rutosky FW, Putnam DJ. 1984. Concentrations of Environmental Contaminants from Selected Waters in Pennsylvania. U. S. Fish Wildl. Serv. Rep., State College: Pennsylvania; 102.

Sa'id MD. 2006. Determination of Lithium, Sodium, and Potassium in four different species of fish. Biol. and Environ. Sci. J. for the Tropics, 3(4): $61-68$.

Shrivastava VS, Indrajit S, Ajay S. 2011. Study for determination of heavy metals in fish species of the River Yamuna (Delhi) by inductively coupled plasmaoptical emission spectroscopy (ICP-OES). Advances in Appl. Sci. Res., 2(2): 161 166.

Sivaperumal P, Sankar T, Viswanathan Nasir P. 2007. Heavy metal concentrations in fish, shellfish and fish product from internal markets of India vis-a-vis international standards. Food Chemistry. 102: $612-620$.

USFDA. 1993a. Food and Drug Administration, Guidance Document for Chromium in Shellfish. DHHS/PHS/FDA/CFSAN/office of seafood: Washington D. C.

USFDA. 1993b. Food and drug Administration, Guidance Document for Nickel in Shellfish. DHHS/PHS/FDA/CFSAN/office of seafood: Washington D. C.

WHO (World Health Organization). 1985. Guidelines for Drinking Water Quality (ii): Health Criteria and Supporting Information, Recommendations (Vol. 1). WHO: Geneva; 130.

WHO (World Health Organization). 1989. National Research Council Recommended Dietary Allowances $\left(10^{\text {th }}\right.$ edn). National Academy Press: Washngton, DC., USA.

Yilmaz F. 2009. The comparison of heavy metal concentrations $(\mathrm{Cd}, \mathrm{Cu}, \mathrm{Mn}, \mathrm{Pb}$ and $\mathrm{Zn}$ ) in tissues of three economically important fish (Anguilla Anguilla, Mugil cephalus and Oreochromis niloticus) Inhabiting Köycegiz Lake-Mugla (Turkey). Turkish Journal of Science \& Technology, 4(1): 7 - 15 . 